\title{
Conservation implications of behavioural interactions between the Giant African Snail and a Native Brazilian species
}

\section{Marcel Miranda \& Iracy Pecora}

To cite this article: Marcel Miranda \& Iracy Pecora (2017) Conservation implications of behavioural interactions between the Giant African Snail and a Native Brazilian species, Ethology Ecology \& Evolution, 29:3, 209-217, DOI: 10.1080/03949370.2015.1125951

To link to this article: https://doi.org/10.1080/03949370.2015.1125951

Published online: 24 Feb 2016.

Submit your article to this journal $\left[\begin{array}{c} \\ \end{array}\right.$

ЦIl Article views: 163

View Crossmark data $\subset$ 


\title{
Conservation implications of behavioural interactions between the Giant African Snail and a Native Brazilian species
}

\author{
Marcel Miranda $^{1, *}$ and Iracy Pecora ${ }^{2}$ \\ ${ }^{1}$ Departamento de Biologia Animal, Universidade Estadual de Campinas, Instituto de \\ Biologia, Rua Monteiro Lobato 255, Campinas, Brazil \\ ${ }^{2}$ Instituto de Biociências, Campus do Litoral Paulista, Universidade Estadual Paulista \\ "Júlio de Mesquita Filho", Praça Infante Dom Henrique s/n, São Vicente, Brazil
}

Received 2 June 2015, accepted 24 November 2015

The Giant African Snail Achatina fulica is widely considered one of the most invasive species in the world. Megalobulimus paranaguensis is a snail endemic to the Brazilian Atlantic Rainforest. Data on possible interactions between A. fulica and terrestrial mollusc species are scarce. We tested whether the presence of $A$. fulica affects the behaviour of $M$. paranaguensis. We put three individuals of A. fulica and three individuals of $M$. paranaguensis in the same aquarium and quantified the time spent in seven behaviours, during three nights ( $n=72$ individuals for A. fulica and $M$. paranaguensis). We also tested the effect of sexual maturity, putting juvenile and adult individuals of both species in the same aquarium. We found behavioural differences between species, among individuals exposed to interspecific interactions and in interactions between these factors, but there was no difference in behaviour between juveniles and adults in the same species and between species. Achatina fulica changed its behaviour in interspecific interaction, becoming more active than usual, but $M$. paranaguensis did not change its behaviour in the presence of the alien species. Our results show that interspecific interaction has an effect on the behavioural patterns of the alien species, and the main factor negatively impacting Megalobulimus populations in Brazil is probably the non-specific control of A. fulica and the alteration and destruction of its habitats.

KEY WORDS: Megalobulimus paranaguensis, Achatina fulica, biological invasion, native invertebrates, competitive exclusion.

\section{INTRODUCTION}

Alien species are a significant ecological problem. Competition for resources usually occurs between native and alien species (Bøhn et al. 2007) and can alter natural

*Corresponding author: Marcel Miranda, Departamento de Biologia Animal, Universidade Estadual de Campinas, Instituto de Biologia, Rua Monteiro Lobato 255. CEP: 13083-970 Campinas, Brazil (E-mail: marcelsmiranda@gmail.com). 
communities (Parker et al. 1999). Niche overlap is usually high in this situation, and intense competition may lead to rapid decline and even the extinction of native populations (Novacek \& Cleland 2001; Webb et al. 2002; Bøhn et al. 2007). The interactions between native and alien species are multifaceted, and include hybridisation, introgression, mutualisms, behavioural and trait shifts, direct predation, niche displacement and competitive exclusion, and can result in extinction (Mooney \& Cleland 2001).

The Giant African Snail, Achatina fulica Bowdich 1822, is considered one of the most highly invasive species in the world (Lowe et al. 2004), with numerous associated negative environmental impacts. This snail can act as an intermediate host of several nematode species, including Angiostrongylus cantonensis (Chen 1935), which causes eosinophilic meningoencephalitis (Teles et al. 1997; Caldeira et al. 2007). Thus, both the parasite and its host represent a public health concern in Brazil as they are present in many Brazilian states (Thiengo et al. 2007, 2013). Achatina fulica is a generalist species in terms of its diet (Albuquerque et al. 2008), and one snail can lay clutches of up to 400 eggs, with an annual production of up to 1200 eggs (Rault \& Baker 2002). On the islands in the Pacific and Indian Oceans, biological control efforts against A. fulica (including the introduction of predatory snails and flatworms) have caused the extinction or decline of endemic island species of land snails (Cowie 1992, 1998, 2001; Civeyrel \& Simberloff 1996; Sugiura et al. 2011; Holland et al. 2012), due to the general predatory habits of the introduced predators. However, neither competition between $A$. fulica and the native fauna nor any other negative effects were demonstrated in these studies, despite reported predation by A. fulica on invasive veronicelid slugs in Hawaii (Meyer et al. 2008). This observation, especially when combined with the biological characteristics of this species, suggests that A. fulica may pose a threat to native land snail fauna.

Megalobulimus paranaguensis (Pilsbry \& Ihering 1900) was originally described in the Brazilian state of Paraná, as well as in Peruíbe and Iguape, southern coastal cities in the state of São Paulo (Morretes 1954; Simone 2006) and the north of Santa Catarina State (Agudo-Padron 2014). The species exhibits low population density (Eston et al. 2006) and, like various native terrestrial mollusc species (Simone 1999), exhibits low reproductive potential, laying only $2-5$ eggs per clutch (Sobreira \& Molina 2002). It buries itself in the soil or leaf litter of rainforests during the day and during its dormancy period (Bequaert 1948; Morretes 1952). The species also exhibits unusually high longevity, and can reach 35.5 years of age (Fontenelle \& Miranda 2012). The population dynamics of the genus is poorly understood because these species are cryptic, and not commonly observed. Many species in the genus Megalobulimus are endangered because they are often mistaken for the giant African snail A. fulica and killed (Colley \& Fischer 2009). They are also endangered because of the degradation of their natural habitat (Bequaert 1948; Miranda et al. 2015). A number of studies report population declines (Fischer \& Colley 2005), probably due to large-scale deforestation that has occurred in some regions of Brazil (Bequaert 1948), and some data suggest risk of extinction of certain species (Leme 1989; Leme \& Indrusiak 1990). Moreover, climate change may pose an additional threat for species of the genus (Beltramino et al. 2015).

Studies focusing on interactions among species of terrestrial molluscs that inhabit the same habitat are scarce. It has been suggested that interference among terrestrial snails may be mediated through aggressive behaviour (Cook 2001; Meyer et al. 2008; Kimura \& Chiba 2010) or through the production of mucus (Cameron \& Carter 1979; Tattersfield 1981; Pearce 1997; Cook 2001). However, few studies have provided explicit evidence of interspecific interactions among land snails, and these studies have been 
restricted to European (e.g. Cameron \& Carter 1979), and Japanese (Kimura \& Chiba 2010) environments. Miranda et al. (2015) found A. fulica and M. paranaguensis occurring within the same habitat on the Brazilian island Ilha Porchat, located in São Vicente, but they did not find negative interactions between them when they investigated spatial niche overlap. Little is known about interaction between land snails in other environments, especially among native and alien land snail species, and behavioural studies can be informative for understanding this interaction. In this study, we tested whether the presence of the alien snail A. fulica affects the behaviour of the adults and juveniles of the native Brazilian species $M$. paranaguensis. Here we tested the hypothesis that the presence of $A$. fulica changes the behavioural pattern and/or activity pattern of $M$. paranaguensis.

\section{MATERIAL AND METHODS}

We collected snails from Ilha Porchat $\left(23^{\circ} 58^{\prime} 46^{\prime \prime} \mathrm{S}, 46^{\circ} 22^{\prime} 08^{\prime \prime} \mathrm{W}\right)$, part of the city of São Vicente, in São Paulo, Brazil, and from the mollusc collection of the Biosciences Institute in the Coastal Campus of São Paulo State University (UNESP). We measured the shell length of each snail using a digital caliper with a precision of $0.01 \mathrm{~mm}$. The specimens received water, lettuce and canary bird vitamins ad libitum. We divided the A. fulica specimens into two groups: juvenile (shell length $<40 \mathrm{~mm}$ ) and adult (shell length $>70 \mathrm{~mm}$ ), according to Kondo (1964). We did not use the young adults (40-70 $\mathrm{mm}$ shell length) because the animals were not sexually mature (Kondo 1964). In the case of M. paranaguensis, we determined sexual maturity based on the presence of the outer lip in the shell (Bequaert 1948), and we then separated the specimens into groups of juveniles and adults. We acclimated the snails to the experimental conditions in the laboratory for 3 days: $23.5^{\circ} \mathrm{C}, 75 \%$ relative humidity, a photoperiod of $12 \mathrm{hr}$ light $/ 12 \mathrm{hr}$ dark, and $50 \times 20 \times 20 \mathrm{~cm}$ aquariums. We filmed the interactions during the dark $12 \mathrm{hr}$ period, because both species are nocturnal (Bequaert 1948; Tomiyama 2000; Rault \& Baker 2002). We inserted three individuals per species with the other species, in the same aquarium with food and water ad libitum, for a total of six specimens in the same terrarium. We also tested the effect of sexual maturity in interspecific interaction, putting juvenile individuals of one species with the adults of the other species. Each experiment was repeated 3 times, and different snails were used in all cases.

Behavioural data were based on $5184 \mathrm{hr}$ of film (36 hr per snail). We recorded the time frequency of seven behaviours for each specimen: (1) Retracted into the shell - this is a perfectly quiet state in which the animal may assume one of two stances: (a) retracted into the shell, with the border of the mantle forming a kind of collar around the foot, exposing the pneumostome; or (b) partially retracted, showing the border of the foot close to the cephalic region, which is retracted into the shell (Romero \& Hoffmann 1991); (2) Still with local activity - the head and foot are out of the shell, and the animal may be: (a) alert: partially or completely extended with tentacle movements, without displacements; (b) making oscillatory movements: this state is similar to the previous state, but with the addition of rhythmic movements of the head, which oscillates horizontally or (c) with complex oscillatory movements: the animal moves the head up and down and back and forth rhythmically through arcs of different angles between the horizontal and frontal planes (Romero \& Hoffmann 1991); (3) Locomotion - the animal is completely extended, showing the oscillatory movements of the tentacles. When the animal is crawling over glass, locomotory waves may be observed on the sole of the foot. The animal's locomotion is unequivocal (Jurberg et al. 1988; Romero \& Hoffmann 1991; Junqueira et al. 2003); (4) Eating - the animal's head is lightly retracted into its body with the tentacles lowered. Rhythmic movements of mouth structures may be seen, promoting food displacement (Jurberg et al. 1988; Romero \& Hoffmann 1991; Junqueira et al. 2003); (5) Vertical locomotion - the animal moves around on the walls of the aquarium, and it makes oscillatory movements of head and tentacles similar to those seen during locomotion (Junqueira et al. 2003); (6) Interaction between individuals - the animal uses its 
tentacles to touch the tentacles, shell or body of another individual, or it raises the shell of another animal (Junqueira et al. 2003); and (7) Watering - the animal enters the water and remains motionless or moves around with tentacles outstretched, making small movements in contact with water (Jurberg et al. 1988).

According to Minoretti et al. (2011), the frequencies of each type of behaviour are not independent from each other, and multivariate analyses are necessary for data analysis. We used a principal components analysis (PCA) with an arcsine transformation to convert the nonindependent data that represented the different types of behaviour into uncorrelated variables for each individual, and then to verify differences in behavioural patterns documented in the experiment. With the same data, permutational multivariate analysis of variance (PERMANOVA; Anderson 2001) was used with three factors (species, sexual maturity and interspecific interaction) with 999 permutations, to see which factor influenced the behavioural pattern.

\section{RESULTS}

We found differences in behaviour between species and among individuals exposed to interspecific interaction, and in the interaction between these factors (Table 1). With the PCA, the activity pattern was successfully explained in the first axis, which explained $59.4 \%$ of the variation in the data (Fig. 1). The behaviour of retracting into the shell had the largest positive eigenvector in the first axis, while the other behaviours had negative eigenvalues. Among other behaviours, vertical locomotion had a large eigenvector (Table 2). Specimens with positive values in the first axis of PCA were less active (they spent more time retracted into the shell), while specimens with negative values were more active (they spent more time engaged in other behaviours, especially vertical locomotion). In the second axis which explained $20.4 \%$ of the data, the behaviours of eating and vertical locomotion had the largest eigenvectors, with opposite sign, and in the third axis, which explained $10.2 \%$ of the data, the behaviours locomotion and eating had the largest eigenvectors, also with opposite signals. PCA differentiated A. fulica with and without interaction. Individuals in interaction became more active than usual and engaged in much more vertical locomotion. In M. paranaguensis, there were no differences between individuals with or without interaction. In the descriptive data, A. fulica specimens were

Table 1.

Results of permutational analyses of variance (PERMANOVA). Significant values are marked with an asterisk.

\begin{tabular}{lcccc}
\hline Factor & df & MS & F & $P$ \\
\hline Species & 1 & 0.587 & 19.903 & $0.001^{*}$ \\
Maturity & 1 & 0.014 & 0.491 & 0.667 \\
Interaction & 1 & 0.111 & 3.768 & $0.017^{*}$ \\
Species/maturity & 1 & 0.008 & 0.279 & 0.81 \\
Species/interaction & 1 & 0.121 & 4.104 & $0.009^{*}$ \\
Maturity/interaction & 1 & 0.003 & 0.119 & 0.925 \\
Species/maturity/interaction & 1 & 0.000 & 0.000 & 1 \\
Residuals & 136 & 0.029 & & \\
\hline
\end{tabular}

MS: mean square. 


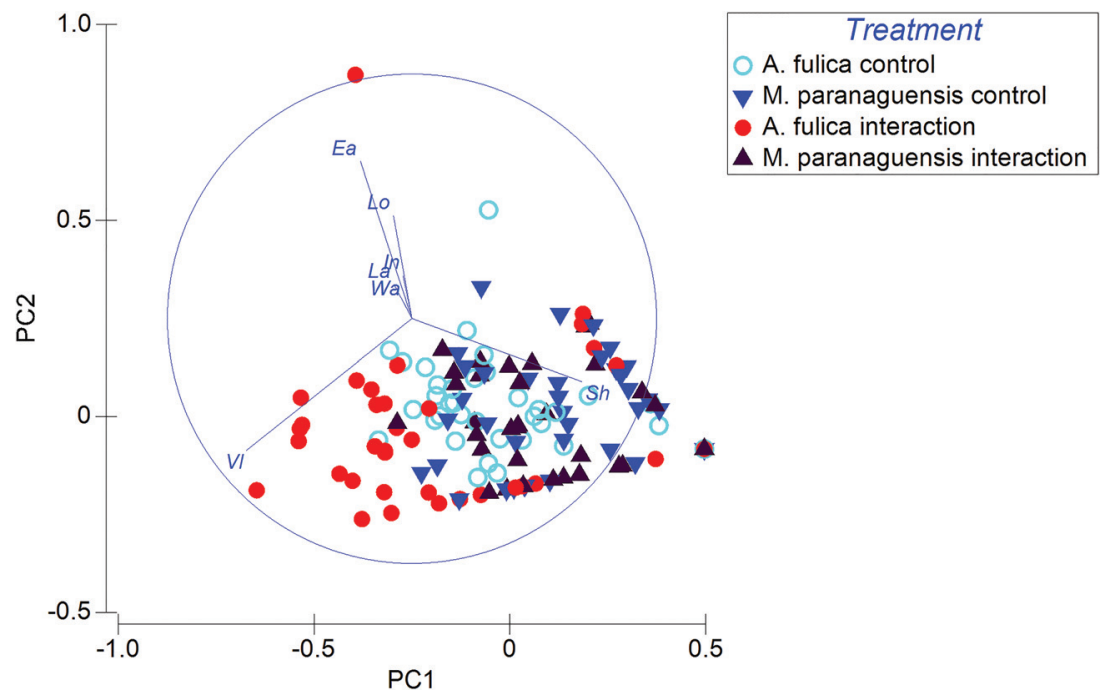

Fig. 1. - Principal component analysis (PCA) biplot for the experiment. Vector captions: Sh $=$ retracted into the shell; $\mathrm{La}=$ still with local activity; Lo = locomotion; $\mathrm{Ea}=$ eating; $\mathrm{Vl}$ = vertical locomotion; $\mathrm{In}=$ interaction between individuals; $\mathrm{Wa}=$ watering.

Table 2.

Principal component analysis (PCA) results of the experiment.

\begin{tabular}{lrrr}
\hline & PC1 & PC2 & \multicolumn{1}{c}{ PC3 } \\
\hline Eigenvalues & 0.067 & 0.023 & 0.011 \\
Proportion explained & $59.4 \%$ & $20.4 \%$ & $10.2 \%$ \\
Cumulative proportion & $59.4 \%$ & $79.8 \%$ & $90.0 \%$ \\
Eigenvectors & & & \\
Retracted into the shell & 0.695 & -0.257 & 0.075 \\
Still with local activity & -0.073 & 0.139 & -0.101 \\
Eating & -0.211 & 0.643 & 0.594 \\
Locomotion & -0.075 & 0.420 & -0.787 \\
Vertical locomotion & -0.678 & -0.538 & -0.002 \\
Interaction & -0.037 & 0.176 & -0.082 \\
Watering & -0.035 & 0.067 & -0.064 \\
\hline
\end{tabular}

found to be more active, spending less time retracted into the shell and more time performing other behaviours, while $M$. paranaguensis was found to be less active, spending more time retracted into the shell (Table 3). When interacting, A. fulica had a significant change in its behavioural pattern: it further reduced its retraction into the shell and significantly increased its vertical locomotion. For M. paranaguensis, no differences in behaviour were observed. 
Table 3.

Mean values of the percentages of behaviours analysed. Standard deviations are shown in parentheses.

\begin{tabular}{lcccc}
\hline Behaviour & $\begin{array}{c}\text { A. fulica } \\
\text { control }\end{array}$ & $\begin{array}{c}\text { A. fulica with } \\
\text { interaction }\end{array}$ & $\begin{array}{c}\text { M. paranaguensis } \\
\text { control }\end{array}$ & $\begin{array}{c}\text { M. paranaguensis with } \\
\text { interaction }\end{array}$ \\
\hline $\begin{array}{l}\text { Retracted into } \\
\text { the shell }\end{array}$ & $81.45(8.52)$ & $72.52(16.12)$ & $89.19(7.54)$ & $88.40(7.56)$ \\
$\begin{array}{l}\text { Still with local } \\
\text { activity }\end{array}$ & $1.44(2.13)$ & $1.34(2.03)$ & $0.34(0.64)$ & $0.16(0.32)$ \\
$\begin{array}{l}\text { Eating } \\
\text { Locomotion }\end{array}$ & $2.61(4.19)$ & $3.61(9.98)$ & $2.01(2.83)$ & $1.61(3.06)$ \\
$\begin{array}{l}\text { Vertical } \\
\text { locomotion }\end{array}$ & $9.00(2.89)$ & $1.65(2.48)$ & $1.82(2.73)$ & $2.73(3.14)$ \\
$\begin{array}{l}\text { Interaction } \\
\text { Watering }\end{array}$ & $0.24(0.48)$ & $0.62(0.81)$ & $5.53(6.66)$ & $6.69(5.53)$ \\
\hline
\end{tabular}

\section{DISCUSSION}

Our results show that interspecific interaction has an effect on the behavioural patterns of the alien species A. fulica, but we observed no evidence of an effect of the presence of $A$. fulica on the native species $M$. paranaguensis. Achatina fulica became more active and moved more frequently in the presence of $M$. paranaguensis. In this case, A. fulica also prefered to perform more vertical locomotion than usual in order to remain in different spatial regions. Achatina fulica tended to be more active and more fully explored its environment, while $M$. paranaguensis was generally less active, including in the presence of the second species. These results explain the data from the field study by Miranda et al. (2015), which analysed spatial niche overlap. In this study, no effects of interspecific competition between these species were detected. Sympatric species may avoid competition by altering any of their behaviours that directly affect the utilisation of limited resources (Cook 2001). It is widely accepted that niche differentiation is often the basis for the coexistence of competitors (MacArthur \& Levins 1967). Interspecific competition favours niche differentiation between competitors because it is often asymmetric, and also because the dominant and subordinate species may optimise their behaviour in different ways (Maynard-Smith \& Parker 1976). In this study, A. fulica and M. paranaguensis were found to have different activity patterns, and these differences could minimise any effects of competition between them. Differences in activity patterns were also found by Asami (1993) in a study on Polygiridae snails that were present in the leaf litter of Appalachian forests.

Similarly to Minoretti et al. (2011), the PCA evidenced that the behaviour "retracted into the shell" occurred more frequently. According to Romero \& Hoffmann (1991), this behavioural pattern indicates less activity.

The effects of interference among terrestrial snails and slugs, like aggressive behaviour (Cook 2001; Meyer et al. 2008; Kimura \& Chiba 2010) or the production of mucus (Cameron \& Carter 1979; Tattersfield 1981; Pearce 1997; Cook 2001) were not observed in this study, although there have been reports of aggressive interactions 
between A. fulica and an invasive species of slug in Hawaiian islands (Meyer et al. 2008). These behaviours may be rare in nature, or they may occur under unusual conditions, such as a limited food supply or during the return to aestivation.

From the results of this paper, the main factor that may be considered to be affecting Megalobulimus populations is the effort to control A. fulica populations, and actions that contribute to the degradation of their natural habitat. Examples of this degradation include soil contamination with salt (Fischer \& Colley 2005), and capturing and accidental killing of $M$. paranaguensis during A. fulica control efforts (Colley \& Fischer 2009), since $M$. paranaguensis superficially resembles A. fulica (Thiengo et al. 2007). Consequently, these control activities may reduce the lifespan of $M$. paranaguensis, as suggested by Miranda et al. (2015). The effect of flawed control policies against A. fulica and the decline of native land snail fauna have been reported by Cowie $(1992,1998,2001)$, as well as by Civeyrel and Simberloff (1996). However, long-term ecological and behavioural studies are necessary in order to quantify and understand the threat posed to Brazilian land snail fauna by the establishment of invasive A. fulica.

\section{ACKNOWLEDGEMENTS}

We would like to thank our colleagues who helped to collect snails on Ilha Porchat (Michel Angeloni, Pedro Moura, Sérgio Júnior and Rafael Bernardes), as well as those who helped with the experiments (Lucas Correia and Gabriele Santos).

\section{DISCLOSURE STATEMENT}

No potential conflict of interest was reported by the authors.

\section{FUNDING}

The Sao Paulo State Research Foundation (FAPESP; Process No. 2013/00670 - 6) provided a grant to the first author, and the Sao Paulo State University Graduate Department of Research (PROPe - UNESP; Process No. 0014/010/13) provided financial support for the laboratory experiments.

\section{REFERENCES}

Agudo-Padron AI. 2014. Inventario sistemático de los moluscos continentales ocurrentes en el Estado de Santa Catarina, Brasil. Bioma. 2:6-23.

Albuquerque FS, Peso-Aguiar MC, Assunção-Albuquerque MJT. 2008. Distribution, feeding behavior and control strategies of the exotic land snail Achatina fulica (Gastropoda: Pulmonata) in the northeast of Brazil. Braz J Biol. 68:837-842.

Anderson MJ. 2001. A new method for non-parametric multivariate analysis of variance. Austral Ecol. 26:32-46.

Asami T. 1993. Divergence of activity patterns in coexisting species of land snails. Malacologia. 35:399-406.

Beltramino AA, Vogler RE, Gutiérrez-Gregoric DE, Rumi A. 2015. Impact of climate change on the distribution of a giant land snail from South America: predicting future trends for setting 
conservation priorities on native malacofauna. Climatic Change. 131:621-633. doi:10.1007/ s10584-015-1405-3

Bequaert JC. 1948. Monograph of the Strophocheilidae, a neotropical family of terrestrial mollusks. Bull Museum Comp Zool. 100:1-210.

Bøhn T, Amundsen P-A, Sparrow A. 2007. Competitive exclusion after invasion?. Biol Invasions. 10:359-368. doi:10.1007/s10530-007-9135-8

Caldeira RL, Mendonça CLGF, Goveia CO, Lenzi HL, Graeff-Texteira C, Lima WS, Mota EM, Pecora IL, Zigiotto de Medeiros AM, dos Santos Carvalho O. 2007. First record of molluscs naturally infected with Angiostrongylus cantonensis (Chen, 1935) (Nematoda: Metastrongylidae) in Brazil. Mem Inst Oswaldo Cruz. 102:887-889.

Cameron RAD, Carter MA. 1979. Intra- and interspecific effects of population density on growth and activity in some helicid land snails (Gastropoda: Pulmonata). J Anim Ecol. 48:237-246.

Civeyrel L, Simberloff D. 1996. A tale of two snails : is the cure worse than the disease? Biodivers Conserv. 5:1231-1252.

Colley E, Fischer ML. 2009. Avaliação dos problemas enfrentados no manejo do caramujo gigante africano Achatina fulica (Gastropoda: Pulmonata) no Brasil. Zoologia. 26:674-683.

Cook A. 2001. Behavioral ecology: On doing the right thing, in the right place at the right time. In: Baker GM, editor. The biology of terrestrial molluscs. 1st ed. New York: CAB International; p. 447-488.

Cowie RH. 1992. Evolution and extinction of Partulidae, endemic Pacific Island Land Snails. Philos Trans R Soc B Biol Sci. 335:167-191.

Cowie RH. 1998. Patterns of introduction of non-indigenous non-marine snails and slugs in the Hawaiian Islands. Biodivers Conserv. 368:349-368.

Cowie RH. 2001. Decline and homogenization of Pacific faunas: the land snails of American Samoa. Biol Conserv. 99:207-222.

Eston MR, Menezes GV, Antunes AZ, dos Santos ASR, dos Santos AMR. 2006. Espécie invasora em unidade de conservação: Achatina fulica (Bowdich, 1822) no Parque Estadual Carlos Botelho, Sete Barras, SP, Brasil. Rev Inst Flor. 18:173-179.

Fischer ML, Colley E. 2005. Espécie invasora em reservas naturais: caracterização da população de Achatina fulica Bowdich, 1822 (Mollusca - Achatinidae) na Ilha Rasa, Guaraqueçaba, Paraná, Brasil. Biota Neotrop. 5:1-18.

Fontenelle JH, Miranda MS. 2012. The use of outer lip in age estimation of Megalobulimus paranaguensis (Gastropoda, Pulmonata). Strombus. 19:15-22.

Holland BS, Chock T, Lee A, Sugiura S. 2012. Tracking behavior in the snail Eugladina rosea: First evidence of preference for endemic vs. biocontrol target pest species in Hawaii. Am Malac Bull. 30:153-157. doi:10.4003/006.030.0113

Junqueira FO, D’Ávila S, Bessa ECA, Prezoto F. 2003. Ritmo de atividade de Bradybaena similaris (Férussac, 1821) (Mollusca, Xanthonychidae) de acordo com a idadea. Rev Etol. 5:41-46.

Jurberg P, Barros HM, Gomes LAL, Coelho ACS. 1988. Superfamília Bulimuloidea do Brasil. Bulimulidae: Thaumasthus (Thaumasthus) taunasii (Férussac, 1821), com dados biológicos e aspectos comportamentais (Mollusca, Gastropoda, Pulmonata). Bol Mus Nac. 317:1-40.

Kimura K, Chiba S. 2010. Interspecific interference competition alters habitat use patterns in two species of land snails. Evol Ecol. 24:815-825. doi:10.1007/s10682-009-9339-8

Kondo Y. 1964. Growth rates in Achatina fulica Bowdich. Nautilus (Philadelphia). 78:6-15.

Leme JLM. 1989. Megalobulimus lopesi sp. n., uma nova espécie de Pulmonata da Mata Atlântica Brasileira (Mollusca, Gastropoda, Megalobulimidae). Mem Inst Oswaldo Cruz. 84:313-318.

Leme JLM, Indrusiak LF. 1990. Megalobulimus parafragilior sp. n., uma nova espécie de Pulmonata terrestre da Serra do Mar (Gastropoda, Megalobulimidae). Pap Avulsos Zool. 37:97-105.

Lowe S, Browne M, Boudjelas S. 2004. 100 of the world's worst invasive alien species. A selection from the global invasive species database [Internet]. [cited 2012 Jan 31]. Available from: http://www.issg.org/database

MacArthur R, Levins R. 1967. The limiting similarity, convergence, and divergence of coexisting species. Am Nat. 101:377-385. 
Maynard-Smith J, Parker GA. 1976. The logic of asymmetric contests. Anim Behav. 24:159-175.

Meyer WM III, Hayes KA, Meyer AL. 2008. Giant African snail, Achatina fulica, as a snail predator. Am Malacol Bull. 24:117-119. doi:10.4003/0740-2783-24.1.117

Minoretti N, Schmera D, Kupfernagel S, Zschokke S, Armbruster GFJ, Beese K, Baur A, Baur B. 2011. Determinants of female and male reproductive success in a simultaneous hermaphrodite land snail. Anim Behav. 82:707-715. doi:10.1016/j.anbehav.2011.06.026

Miranda MS, Fontenelle JH, Pecora IL. 2015. Population structure of a native and an alien species of snail in an urban area of the Atlantic Rainforest. J Nat Hist. 49:19-35. doi:10.1080/ 00222933.2014 .930756

Mooney HA, Cleland EE. 2001. The evolutionary impact of invasive species. PNAS. [Internet]. 98:5446-5451. doi:10.1073/pnas.091093398

Morretes FL. 1952. Novas espécies brasileiras da família Strophocheilidae. Arq Zool. 8:109-128.

Morretes FL. 1954. Sôbre Megalobulimus paranaguensis Pilsbry \& Iering. Arq Mus Parana. 10:343-344.

Novacek MJ, Cleland EE. 2001. The current biodiversity extinction event: Scenarios for mitigation and recovery. Proc Natl Acad Sci USA. 98:5466-5470. doi:10.1073/pnas.091093698

Parker IM, Simberloff D, Lonsdale WM, Goodell K, Wonham M, Kareiva PM, Williamson MH, Von Holle B, Moyle PB, Byers JE, et al. 1999. Impact: toward a framework for understanding the ecological effects of invaders. Biol Invasions. 1:3-19.

Pearce TA. 1997. Interference and resouce competition in two land snails: Adults inhibit conspecific juvenile growth in field and laboratory. J Molluscan Stud. 63:389-399.

Rault SK, Baker GM. 2002. Achatina fulica Bowdich and other Achatinidae as pests in tropical agriculture. In: Baker GM, editor. Molluscs as crop pests. New York: CAB International; p. 55-114.

Romero SMB, Hoffmann A. 1991. Heart rate and behavioral patterns of Megalobulimus sanctipauli (Mollusca, Gastropoda, Pulmonata). Braz J Med Biol Res. 24:223-227.

Simone LRL. 1999. Gastropoda terrestres. In: Brandão CRF, Cancello EM, editors. Biodiversidade do estado São Paulo síntese do conhecimento ao final do século XX. Vol. 5, Invertebrados Terrestres. 1st ed. São Paulo (Brazil): FAPESP; p. 3-8.

Simone LRL. 2006. Land and freshwater molluscs of Brazil. São Paulo (Brazil): EGB, FAPESP.

Sobreira HB, Molina FB. 2002. Observações preliminares sobre a biologia reprodutiva de Megalobulimus gummatus (Mollusca, Megalobulimidae) em laboratório. Arq Inst Biol (Sao Paulo). 69:139-141.

Sugiura S, Holland BS, Cowie RH. 2011. Predatory behavior in juvenile Eugladina rosea. J Molluscan Stud. 77:101-102. doi:10.1093/mollus/eyq042

Tattersfield P. 1981. Density and environmental effects on shell size in some sand dune snail populations. Biol J Linn Soc. 16:71-81.

Teles HMS, Vaz JF, Fontes RL, Domingos MF. 1997. Registro de Achatina fulica Bowdich, 1822 (Mollusca, Gastropoda) no Brasil: caramujo hospedeiro intermediário da angiostrongilíase occurrence of Achatina fulica Bowdich, 1822. Rev Saude Publica. 31:1996-1998.

Thiengo SC, Faraco FA, Salgado NC, Cowie RH, Fernandez MA. 2007. Rapid spread of an invasive snail in South America: the giant African snail, Achatina fulica, in Brasil. Biol Invasions. 9:693-702. doi:10.1007/s10530-006-9069-6

Thiengo SC, Simões RO, Fernandes MA, Maldonado A. Jr. 2013. Angiostrongylus cantonensis and Rat Lungworm disease in Brazil. Hawaii J Med Public Health. 72:18-22.

Tomiyama K. 2000. Daily dispersals from resting sites of the Giant African Snail, Achatina fulica (Ferussac) (Pulmonata; Achatinidae), on a North Pacific Island. Tropics. 10:243-249.

Webb CO, Ackerly DD, McPeek MA, Donoghue MJ. 2002. Phylogenies and community ecology. Annu Rev Ecol Syst. 33:475-505. doi:10.1146/annurev.ecolsys.33.010802.150448 